\title{
ANALISIS SISTEM DRAINASE PERUMAHAN DI JALAN DAMAI KOTA SAMARINDA
}

\author{
Yuswal Subhy \\ Dosen Program Studi Teknik Sipil Fakultas Teknik \\ Universitas 17 Agustus 1945 Samarinda, \\ E-mail: yuswalsubhy1971@gmail.com/HP. 082324730106
}

\begin{abstract}
ABSTRAK
Pembangunan perumahan beserta sarana dan prasarananya perlu mendapat prioritas mengingat perumahan merupakan salah satu kebutuhan pokok. Pembangunan Perumahan di Jalan Damai oleh pengembang Kota Samarinda yang terletak di Kecamatan Sambutan merupakan upaya untuk lebih menggiatkan kehidupan ekonomi daerah dan sekitarnya. Dengan dibangunnya perumahan maka otomatis akan mempengaruhi kondisi sistem drainase di sekitar kawasan tersebut. Mengubah jumlah run off merupakan langkah awal yang harus diperhatikan dan dikelola dengan baik. Ada dua jenis distribusi yang digunakan dalam penelitian ini yaitu Distribusi Kayu Pearson III dan Distribusi Gumbel Tipe I. Uji kesesuaian sebaran dilakukan untuk menentukan jenis sebaran yang paling sesuai dengan data curah hujan. Ada dua jenis uji kesesuaian (Goodness of Fit Tests) yaitu Chi Square dan Smirnov - Kolmogorof).NMetode penelitian yang digunakan adalah metode pengumpulan dan analisis data. Data yang digunakan adalah data primer dan data sekunder. Kemudian data dianalisis berdasarkan analisis hidrologi dan analisis hidrolik. Hasil penelitian menunjukkan bahwa dimensi untuk semua saluran pada Perumahan Jl. Damai menggunakan potongan persegi ekonomis dengan periode ulang 10 tahun. Alur Utama 1, kedalaman saluran (h) $30 \mathrm{~cm}$, lebar dasar saluran (B) $50 \mathrm{~cm}$, tinggi pelindung $20 \mathrm{~cm}$, dan debit rencana 0,618 m3 / detik. Alur Utama 2, kedalaman saluran (h) $30 \mathrm{~cm}$, lebar dasar (B) $60 \mathrm{~cm}$, tinggi pelindung $20 \mathrm{~cm}$, dan debit rencana 0,395 m3 / dtk. Alur Utama 3, kedalaman saluran (h) $30 \mathrm{~cm}$, lebar dasar saluran (B) $50 \mathrm{~cm}$, tinggi pelindung $20 \mathrm{~cm}$, dan debit rencana $0,351 \mathrm{~m} 3 / \mathrm{s}$.
\end{abstract}

Kata Kunci: Saluran, Intensitas Hujan, Debit Banjir.

\begin{abstract}
Housing development and its facilities and infrastructure need to be given priority considering that housing is one of the basic needs. Housing Development on Jalan Damai by Samarinda City developer, located in Sambutan District, is an effort to further activate the economic life of the region and its surroundings. With the construction of housing, it will automatically affect the condition of the drainage system around the area. Changin the number of run offs is a first step that must be considered and managed properly. There are two types of distribution used in this study, namely the Pearson III Log Distribution and the Type I Gumbel Distribution. The distribution suitability test was carried out to determine the type of distribution that best suits the rainfall data. There are two types of suitability tests (goodness of Fit Tests), namely Chi Square and SmirnovKolmogorof). The research method used is the method of data collection and analysis. The data used are primary data and secondary data. Then the data were
\end{abstract}


analyzed based on hydrological analysis and hydraulic analysis. Based on the results of the reseacrh it can be concluded that, the dimensions for all channels in housing Jl. Damai uses economical square section with a return period of 10 years. Main Channel 1, channel depth (h) $30 \mathrm{~cm}$, bottom width of channel (B) 50 $\mathrm{cm}$, guard height $20 \mathrm{~cm}$, and design discharge of $0.618 \mathrm{~m}^{3} / \mathrm{s}$. Main Channel 2, channel depth (h) $30 \mathrm{~cm}$, bottom width (B) $60 \mathrm{~cm}$, guard height $20 \mathrm{~cm}$, and design discharge of $0.395 \mathrm{~m}^{3} / \mathrm{s}$. Main Channel 3, channel depth (h) $30 \mathrm{~cm}$, channel base width (B) $50 \mathrm{~cm}$, guard height $20 \mathrm{~cm}$, and design discharge of $0.351 \mathrm{~m}^{3} / \mathrm{s}$.

Keywords: Channels, Rain Intensity, Flood Discharge.

\section{PENDAHULUAN}

Pembangunan perumahan beserta sarana dan prasarananya perlu mendapatkan prioritas mengingat tempat tinggal merupakan salah satu kebutuhan dasar. Adanya keterbatasan lahan dan kebutuhan lahan yang semakin meningkat sejalan dengan pertumbuhan penduduk dan kegiatan sosial ekonomi yang menyertainya, berdampak pada semakin beragamnya fungsi di kawasan perkotaan. Persaingan terjadi untuk mendapatkan pemanfaatan lahan yang paling menguntungkan sehingga dapat mendorong kecenderungan terjadinya perubahan pemanfatan lahan perkotaan dan memicu persaingan investasi dibidang properti terutama kepada perubahan penggunaan tata guna lahan pada kawasan perkotaan. Persyaratan pembangunan perumahan adalah Amdal (Analisa Mengenai Dampak Lingkungan), hal tersebut yang dilakukan oleh pengembang perumahan Jl. Damai di Kota Samarinda. Meningkatnya pembangunan perumahan akan mengakibatkan penggunaan lahan semakin meningkat dan daerah hijau/daerah terbuka yang berfungsi untuk menahan sementara waktu dan meresapkan air hujan kedalam tanah semakin berkurang. Sehingga apabila terjadi hujan, maka di beberapa daerah yang permukaannya sudah dibangun perumahan tingkat infiltrasinya air menjaadi kecil. Apalagi kalau system drainase tidak tertata dengan baik dan memadai akan mengakibatkan genangan atau tidak mampunya saluran drainase untuk mengalirkan limpasan.

Untuk mengatasi genangan yang terjadi akibat perubahan tata guna lahan, salah satu langkah yang perlu diambil adalah dengan memperhatikan sistem pengelolaan air hujan pada suatu kawasan dalam rangka konservasi air, yaitu dengan memperhatikan system drainase dan kolam penampungan sebagai cara untuk mengendalikan banjir.

Sistem drainase merupakan salah satu bagian yang penting dalam perencanaan pembangunan suatu kawasan pemukiman. Sistem drainase yang baik harus dapat menampung pembuangan air semaksimal mungkin, sehingga apabila debit air lebih dari yang diperkirakan, sistem drainase tersebut masih dapat menampung dan mengalirkannya sehingga tidak terjadi genangan air pada saat hujan turun. Selain itu, drainase juga berfungsi untuk mengurangi erosi tanah.

Pembangunan Perumahan Jl. Damai yang berlokasi di Kecamatan Sambutan Kota Samarinda pada Koordinat $(-0.492874,117.174039)$ merupakan usaha untuk lebih menggiatkan kehidupan ekonomi dikawasan tersebut dan sekitarnya. Dengan pembangunan Perumahan Jl. Damai tersebut, otomatis akan mempengaruhi 
kondisi sistem drainase di sekitar wilayah tersebut. Perubahan jumlah limpasan air akan menjadi tolak ukur pertama yang harus diperhatikan dan dikelola dengan baik.

\section{METODOLOGI PENELITIAN}

\section{Populasi dan Sampel}

Populasi dalam Penelitian Analisis Sistem Drainase Perumahaan Jalan Damai adalah seluruh wilayah Kecamatan Sambutan dan yang menjadi sampel dalam penelitian ini yaitu Wilayah Perumahaan Jalan Damai.

\section{Lokasi Penelitian}

Lokasi penelitian Analisis Sistem Drainase Perumahaan Jalan Damai Kecamatan Sambutan kota Samarinda (Gambar 1).

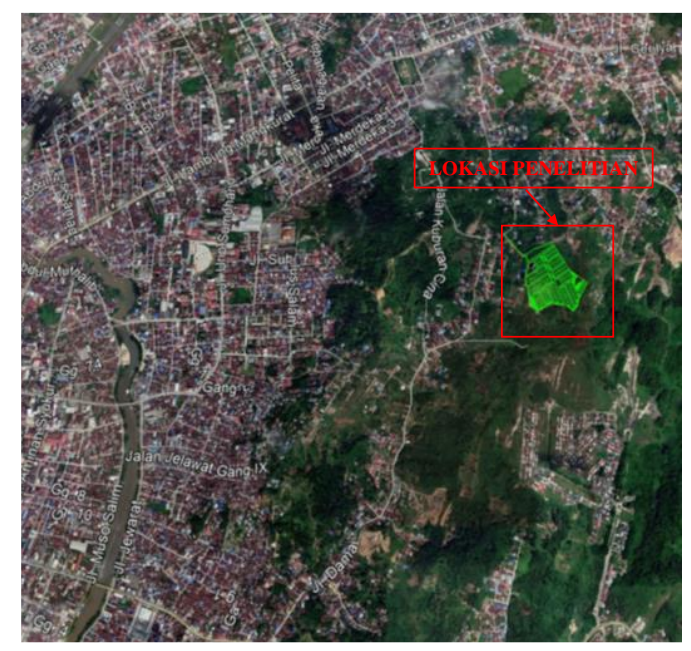

Sumber: Google Earth

\section{Teknik Pengumpulan Data dan Analisa Data}

Data yang dikumpulkan meliputi : type rumah, luas area, saluran exiting, data sekunder, curah hujan, topografi dan kontur tanah. Tahap analisis data merupakan tindak lanjut setelah pengolahan data selesai dilakukan.

\section{HASIL DAN PEMBAHASAN}

\section{Data Curah Hujan}

Dalam penelitian ini dipakai data curah hujan harian kota Samarinda yang di mulai dari tahun 2000 sampai dengan tahun 2019 (20 tahun) disajikan pada Tabel.

Tabel 1. Data Curah Hujan Periode 2000 - 2019

\begin{tabular}{|l|l|c|l|c|c|}
\hline Nomor & Tahun & $\begin{array}{l}\text { Curah Hujan } \\
\text { Harian (Hmin) }\end{array}$ & Nomor & Tahun & $\begin{array}{l}\text { Curah Hujan } \\
\text { Harian (Hmin) }\end{array}$ \\
\hline 1 & 2000 & 83,8 & 11 & 2010 & 86,5 \\
\hline 2 & 2001 & 60,9 & 12 & 2011 & 105,5 \\
\hline 3 & 2002 & 66,3 & 13 & 2012 & 98,9 \\
\hline 4 & 2003 & 76 & 14 & 2013 & 84,3 \\
\hline
\end{tabular}


JURNAL KACAPURI

JURNAL KEILMUAN TEKNIK SIPIL

Volume 4 Nomor 1 Edisi Juni 2021

\begin{tabular}{|l|c|c|l|c|c|}
\hline 5 & 2004 & 118,2 & 15 & 2014 & 102,5 \\
\hline 6 & 2005 & 108 & 16 & 2015 & 78,8 \\
\hline 7 & 2006 & 132,1 & 17 & 2016 & 120,1 \\
\hline 8 & 2007 & 94,4 & 18 & 2017 & 102,3 \\
\hline 9 & 2008 & 132 & 19 & 2018 & 133 \\
\hline 10 & 2009 & 74,2 & 20 & 2019 & 99,7 \\
\hline
\end{tabular}

Sumber: http: //dataonline.bmkg.go.id/data_iklim

\section{Pemilihan Jenis Sebaran}

Perhitungan gumbel

Parameter-parameter statistik dari Distribusi Gumbel Tipe 1 yang dimiliki data diatas adalah:

Nilai rata-rata (mean):

$\overline{\mathrm{X}}=\frac{\sum \mathrm{X}_{\mathrm{i}}}{\mathrm{n}}$

$\bar{X}=\frac{1957,5}{20}=97,875$

Standar Deviasi:

$\mathrm{S}=21,732$

Koefisien kemencengan :

$\mathrm{C}_{\mathrm{s}}=\frac{\mathrm{n} \cdot \sum_{\mathrm{i}=1}^{\mathrm{n}}\left(\mathrm{X}_{\mathrm{i}}-\overline{\mathrm{X}}\right)^{3}}{(\mathrm{n}-1)(\mathrm{n}-2) \mathrm{S}^{3}}$

$\mathrm{C}_{\mathrm{s}}=0,141$

Koefisien ketajaman :

$\mathrm{C}_{\mathrm{k}}=\frac{\mathrm{n}^{2} \mathrm{x} \sum\left(\mathrm{X}_{\mathrm{i}}-\overline{\mathrm{X}}\right)^{4}}{(\mathrm{n}-1) \mathrm{x}(\mathrm{n}-2) \mathrm{x}(\mathrm{n}-3) \mathrm{xS}^{4}}$

$\mathrm{C}_{\mathrm{k}}=2,563$

Contoh Perhitungan Curah hujan Rencana dengan periode ulang 2 Tahun

$\mathrm{X}=\overline{\mathrm{X}}+\frac{\mathrm{S}}{\mathrm{S}_{\mathrm{n}}}\left(\mathrm{Y}_{\mathrm{T}^{-}} \mathrm{Y}_{\mathrm{n}}\right)$

$\mathrm{S}_{\mathrm{n}}=1,0628 \quad($ tabel 2.3$)$

$\mathrm{Y}_{\mathrm{T}}=0,3665 \quad($ tabel 2.4)

$\mathrm{Y}_{\mathrm{n}}=0,5236 \quad$ (tabel 2.2)

$\mathrm{S}=21,732 \quad$ (Perhitungan)

$\overline{\mathrm{X}}=97,875 \mathrm{~mm} \quad$ (Perhitungan)

$X=97,875+\frac{21,732}{1,0628}(0,3665-0,5236)$

$X=97,875+20,448 \times(-0,1571)$

$\mathrm{X}=94,663 \mathrm{~mm}$

Tabel 2. Perhitungan Gumbel

\begin{tabular}{|c|c|c|c|c|c|}
\hline Tahun & $\mathrm{X}_{\mathrm{i}}$ & $\left(\mathrm{X}_{\mathrm{i}}-\overline{\mathrm{X}}\right)$ & $(\mathrm{Xi}-\overline{\mathrm{X}})^{2}$ & $\left(\mathrm{X}_{\mathrm{i}}-\overline{\mathrm{X}}\right)^{3}$ & $\left(\mathrm{X}_{\mathrm{i}}-\overline{\mathrm{X}}\right)^{4}$ \\
\hline 2000 & 83,8 & $-14,075$ & 198,106 & $-2.788,337$ & $39.245,839$ \\
\hline 2001 & 60,9 & $-36,975$ & $1.367,151$ & $-50.550,394$ & $1.869 .100,831$ \\
\hline 2002 & 66,3 & $-31,575$ & 996,981 & $-31.479,663$ & $993.970,367$ \\
\hline 2003 & 76 & $-21,875$ & 478,516 & $-10.467,529$ & $228.977,203$ \\
\hline
\end{tabular}




\begin{tabular}{|c|c|c|c|c|c|}
\hline Tahun & $\mathrm{X}_{\mathrm{i}}$ & $\left(\mathrm{X}_{\mathrm{i}}-\overline{\mathrm{X}}\right)$ & $(\mathrm{Xi}-\overline{\mathrm{X}})^{2}$ & $\left(\mathrm{X}_{\mathrm{i}}-\overline{\mathrm{X}}\right)^{3}$ & $\left(\mathrm{X}_{\mathrm{i}}-\overline{\mathrm{X}}\right)^{4}$ \\
\hline 2004 & 118,2 & 20,325 & 413,106 & $8.396,372$ & $170.656,257$ \\
\hline 2005 & 108 & 10,125 & 102,516 & $1.037,971$ & $10.509,453$ \\
\hline 2006 & 132,1 & 34,225 & $1.171,351$ & $40.089,475$ & $1.372 .062,287$ \\
\hline 2007 & 94,4 & $-3,475$ & 12,076 & $-41,963$ & 145,821 \\
\hline 2008 & 132 & 34,125 & $1.164,516$ & $39.739,096$ & $1.356 .096,641$ \\
\hline 2009 & 74,2 & $-23,675$ & 560,506 & $-13.269,971$ & $314.166,556$ \\
\hline 2010 & 86,5 & $-11,375$ & 129,391 & $-1.471,818$ & $16.741,934$ \\
\hline 2011 & 105,5 & 7,625 & 58,141 & 443,322 & $3.380,332$ \\
\hline 2012 & 98,9 & 1,025 & 1,051 & 1,077 & 1,104 \\
\hline 2013 & 84,3 & $-13,575$ & 184,281 & $-2.501,609$ & $33.959,349$ \\
\hline 2014 & 102,5 & 4,625 & 21,391 & 98,932 & 457,559 \\
\hline 2015 & 78,8 & $-19,075$ & 363,856 & $-6.940,546$ & $132.390,916$ \\
\hline 2016 & 120,1 & 22,225 & 493,951 & $10.978,053$ & $243.987,220$ \\
\hline 2017 & 102,3 & 4,425 & 19,581 & 86,644 & 383,401 \\
\hline 2018 & 133 & 35,125 & $1.233,766$ & $43.336,018$ & $1.522 .177,617$ \\
\hline 2019 & 99,7 & 1,825 & 3,331 & 6,078 & 11,093 \\
\hline JUML & 1957,5 & & $8.973,558$ & $24.701,206$ & $8.308 .421,779$ \\
\hline SUb
\end{tabular}

Sumber : Hasil Perhitungan

Perhitungan Log Pearson Type III

Parameter-parameter statistik dari Distribusi Log Pearson Type III yang dimiliki data tabel 4.4 adalah:

Nilai rata-rata (mean):

$\overline{\log X}=\frac{\sum \log X_{i}}{n}$

$\overline{\log X}=\frac{39,604}{20}=1,980$

Standar Deviasi:

$\mathrm{SLog} \mathrm{Xi}=\sqrt{\frac{\sum \log (\mathrm{Xi}-\overline{\mathrm{X}})^{2}}{\mathrm{n}-1}}$

$\mathrm{SLog} \mathrm{Xi}=0.099$

Koefisien kemencengan :

$\mathrm{C}_{\mathrm{s}}=\frac{\mathrm{n} \cdot \sum_{\mathrm{i}=1}^{\mathrm{n}}\left(\log \mathrm{X}_{\mathrm{i}}-\log \overline{\mathrm{X}}\right)^{3}}{(\mathrm{n}-1)(\mathrm{n}-2) \mathrm{S}^{3}}$

$\mathrm{C}_{\mathrm{s}}=-0,254$

Koefisien variasi :

$\mathrm{C}_{\mathrm{V}}=\frac{\mathrm{S}_{\mathrm{d}}}{\overline{\log \mathrm{X}}}$

$\mathrm{C}_{\mathrm{V}}=0,05$

Contoh perhitungan Logaritma Hujan rencana metode Distribusi Log Pearson Type III dengan Periode Ulang 2 tahun 


\section{$\log \mathrm{X}=\overline{\log X}+\mathrm{K}(\overline{\mathrm{S} \log \mathrm{X}})$}

Nilai K di peroleh dari tabel 2.5 dengan interpolasi berdasarkan nilai Cs $=-0,2536$ Di Interpolasikan $\mathrm{K}=0,042$

Nilai K hasil interpolasi untuk kala ulang 5 dan 10 tahun di sajikan pada tabel 4.5 berikut :

Tabel 3. Nilai K Hasil Interpolasi berdasarkan nilai Cs $=-0,2536$

\begin{tabular}{|c|c|c|}
\hline Nomor & Kala Ulang (Tahun) & Harga K \\
\hline 1 & 2 & 0,042 \\
\hline 2 & 5 & 0,852 \\
\hline 3 & 10 & 1,251 \\
\hline
\end{tabular}

Sumber : Hasil Perhitungan

Perhitungan Logaritma Hujan rencana metode Distribusi Log Pearson Type III dengan Periode Ulang 2 tahun

$\log \mathrm{X}=\overline{\log \mathrm{X}}+\mathrm{K}(\overline{\mathrm{S} \log \mathrm{X}})$

$\log X_{2}=1,980+0,042 \times 0,099$

$\log X_{2}=1,984$

$\mathrm{X}_{2}=10^{1,984}$

$X_{2}=96,460$

Tabel 4. Perhitungan Curah hujan Rencana metode Distribusi Log Person III

\begin{tabular}{|c|c|c|c|}
\hline No. & Kala Ulang (Tahun) & $\log X$ & Hujan Rencana \\
\hline 1 & 2 & 1,984 & 96,460 \\
\hline 2 & 5 & 2,064 & 115,999 \\
\hline 3 & 10 & 2,104 & 127,053 \\
\hline
\end{tabular}

Sumber: Hasil Perhitungan

Tabel 5. Pedoman Umum Penggunaan Metode Distribusi Sebaran

\begin{tabular}{|c|c|c|c|c|c|c|}
\hline No. & $\begin{array}{c}\text { Jenis } \\
\text { Sebaran }\end{array}$ & $\begin{array}{r}\mathrm{H} \\
\text { Perh }\end{array}$ & $\begin{array}{l}\text { il } \\
\text { ngan }\end{array}$ & Syarat & \multicolumn{2}{|c|}{ Keterangan } \\
\hline \multirow{2}{*}{1} & Log Person & $\mathrm{Cs}=$ & $-0,25$ & $\mathrm{Cs} \neq 0$ & Ok & \multirow{2}{*}{$\begin{array}{c}\text { Dapat } \\
\text { diterima }\end{array}$} \\
\hline & III & $\mathrm{Cv}=$ & 0.05 & $\mathrm{CV} \approx 0,3$ & Mendekati & \\
\hline \multirow{2}{*}{2} & \multirow{2}{*}{ Gumbel } & $\mathrm{Cs}=$ & 0.14 & $\begin{array}{l}\mathrm{Cs} \approx \\
1,139 \\
\end{array}$ & Kurang & \multirow{2}{*}{$\begin{array}{c}\text { Belum dapa } \\
\text { diterima }\end{array}$} \\
\hline & & $\mathrm{Ck}=$ & 2,56 & $\begin{array}{l}\mathrm{Ck} \approx \\
5,402\end{array}$ & Kurang & \\
\hline
\end{tabular}

Sumber: Hasil Perhitungan

Dari hasil perhitungan distribusi curah hujan dengan menggunakan Metode Log Person Tipe III dan Metode Gumbel Type I diatas, berdasarkan syarat dari kedua 
metode tersebut maka metode distribusi sebaran yang di gunakan adalah Metode Log Person Tipe III.

Tabel 6. Perhitungan Distribusi Log Pearson Type III

\begin{tabular}{|c|c|c|c|c|c|}
\hline Tahun & $\mathrm{X}_{\mathrm{i}}(\mathrm{mm})$ & $\begin{array}{c}\text { LOG } \\
X_{i}\end{array}$ & $\begin{array}{c}\left(\text { LOG X } \mathrm{i}^{-}\right. \\
\overline{\mathrm{LOG} \mathrm{X}})\end{array}$ & $\begin{array}{l}\text { LOG X X } \\
\overline{\text { LOG X }})^{2}\end{array}$ & $\begin{array}{l}\left(\text { LOG X X } \mathrm{i}^{-}\right. \\
\overline{\mathrm{LOG} \mathrm{X}})^{3}\end{array}$ \\
\hline 2000 & 83,8 & 1,923 & $-0,057$ & 0,003 & $-0,0002$ \\
\hline 2001 & 60,9 & 1,785 & $-0,196$ & 0,038 & $-0,007$ \\
\hline 2002 & 66,3 & 1,822 & $-0,159$ & 0,025 & $-0,004$ \\
\hline 2003 & 76 & 1,881 & $-0,099$ & 0,010 & $-0,001$ \\
\hline 2004 & 118,2 & 2,073 & 0,092 & 0,009 & 0,001 \\
\hline 2005 & 108 & 2,033 & 0,053 & 0,003 & 0,0002 \\
\hline 2006 & 132,1 & 2,121 & 0,141 & 0,020 & 0,003 \\
\hline 2007 & 94,4 & 1,975 & $-0,005$ & 0,00003 & $-1,41 \times 10^{-7}$ \\
\hline 2008 & 132 & 2,121 & 0,140 & 0,020 & 0,003 \\
\hline 2009 & 74,2 & 1,870 & $-0,110$ & 0,012 & $-0,001$ \\
\hline 2010 & 86,5 & 1,937 & $-0,043$ & 0,002 & $-0,0001$ \\
\hline 2011 & 105,5 & 2,023 & 0,043 & 0,002 & 0,0001 \\
\hline 2012 & 98,9 & 1,995 & 0,015 & 0,0002 & $3,39 \times 10^{-6}$ \\
\hline 2013 & 84,3 & 1,926 & $-0,054$ & 0,003 & $-0,0002$ \\
\hline 2014 & 102,5 & 2,011 & 0,031 & 0,001 & 0,00003 \\
\hline 2015 & 78,8 & 1,897 & $-0,084$ & 0,007 & $-0,001$ \\
\hline 2016 & 120,1 & 2,080 & 0,099 & 0,010 & 0,001 \\
\hline 2017 & 102,3 & 2,010 & 0,030 & 0,001 & 0,00003 \\
\hline 2018 & 133 & 2,124 & 0,144 & 0,021 & 0,003 \\
\hline 2019 & 99,7 & 1,999 & 0,019 & 0,0003 & $6,35 \times 10^{-6}$ \\
\hline $\mathrm{Jml}$ & & 39,604 & $-7,327 \times 10^{-15}$ & 0,186 & $-0,004$ \\
\hline
\end{tabular}

\section{Uji Kecocokan Sebaran}

Uji Kecocokan Chi-Square

Tabel 7. Perhitungan Nilai Chi Square Hitung

\begin{tabular}{|c|c|c|c|c|c|c|c|c|c|c|}
\hline No & \multicolumn{5}{|c|}{$\begin{array}{c}\text { Nilai Batas Sub } \\
\text { Kelas (x) }\end{array}$} & \multirow{2}{*}{$\frac{\mathrm{E}_{\mathrm{i}}}{3,333}$} & \multirow{2}{*}{$\frac{\mathrm{O}_{\mathrm{i}}}{1}$} & \multirow{2}{*}{$\begin{array}{l}\mathrm{O}_{\mathrm{i}}-\mathrm{E}_{\mathrm{i}} \\
-2,333\end{array}$} & \multirow{2}{*}{$\frac{\left(\mathrm{O}_{\mathrm{i}}-\mathrm{E}_{\mathrm{i}}\right)^{2}}{5,444}$} & \multirow{2}{*}{$\frac{\left(\mathrm{E}_{\mathrm{i}}-\mathrm{O}_{\mathrm{i}}\right)^{2}}{\mathrm{E}_{\mathrm{i}}}$} \\
\hline 1 & 1,751 & $<$ & $\mathrm{x}$ & $<$ & 1,819 & & & & & \\
\hline 2 & 1,819 & $<$ & $\mathrm{X}$ & $<$ & 1,886 & 3,333 & 3 & $-0,333$ & 0,111 & 0,033 \\
\hline 3 & 1,886 & $<$ & $\mathrm{X}$ & $<$ & 1,954 & 3,333 & 4 & 0,667 & 0,444 & 0,133 \\
\hline 4 & 1,954 & $<$ & $\mathrm{X}$ & $<$ & 2,022 & 3,333 & 5 & 1,667 & 2,777 & 0,833 \\
\hline 5 & 2,022 & $<$ & $\mathrm{X}$ & $<$ & 2,090 & 3,333 & 4 & 0,667 & 0,444 & 0,133 \\
\hline \multirow[t]{2}{*}{6} & 2,090 & $<$ & $\mathrm{X}$ & $<$ & 2,158 & 3,333 & 3 & $-0,333$ & 0,111 & 0,033 \\
\hline & & & & & & 20 & 20 & & & 2,800 \\
\hline
\end{tabular}

Sumber : Hasil Perhitungan

Nilai $\mathrm{X}_{\text {Cr }}^{2}$ Hitung = 2,800; Nilai $\mathrm{X}^{2}$ Cr tabel = 7,815 (Tabel Chi Square)

Kesimpulan :

$\mathrm{X}^{2} \mathrm{Cr}$ hit $<\mathrm{X}^{2} \mathrm{Cr}$ tabel $(2,800<7,815$ (Memenuhi Syarat) 


\section{Uji Kecocokan Smirnov - Kolmogorov}

Tabel 8. Perhitungan Uji Smirnov - Kolmogorov

\begin{tabular}{|c|c|c|c|c|c|c|c|}
\hline $\mathrm{X}$ & $\mathrm{m}$ & $P(X m)=\frac{m}{n+1}$ & $\mathrm{P}(\mathrm{X}<)$ & $f(t)=\frac{X i-X}{S d}$ & $P^{\prime}(X m)=\frac{m}{n-1}$ & $\mathrm{P}^{\prime}(\mathrm{X}<)$ & $\mathrm{D}_{\text {Max }}$ \\
\hline 1,785 & 1 & 0,048 & 0,952 & $-1,976$ & 0,053 & 0,947 & 0,00501 \\
\hline 1,822 & 2 & 0,095 & 0,905 & $-1,603$ & 0,105 & 0,895 & 0,01003 \\
\hline 1,870 & 3 & 0,143 & 0,857 & $-1,109$ & 0,158 & 0,842 & 0,01504 \\
\hline 1,881 & 4 & 0,190 & 0,810 & $-1,004$ & 0,211 & 0,789 & 0,02005 \\
\hline 1,897 & 5 & 0,238 & 0,762 & $-0,845$ & 0,263 & 0,737 & 0,02506 \\
\hline 1,923 & 6 & 0,286 & 0,714 & $-0,575$ & 0,316 & 0,684 & 0,03008 \\
\hline 1,926 & 7 & 0,333 & 0,667 & $-0,549$ & 0,368 & 0,632 & 0,03509 \\
\hline 1,937 & 8 & 0,381 & 0,619 & $-0,436$ & 0,421 & 0,579 & 0,04010 \\
\hline 1,975 & 9 & 0,429 & 0,571 & $-0,053$ & 0,474 & 0,526 & 0,04511 \\
\hline 1,995 & 10 & 0,476 & 0,524 & 0,152 & 0,526 & 0,474 & 0,05013 \\
\hline 1,999 & 11 & 0,524 & 0,476 & 0,187 & 0,579 & 0,421 & 0,05514 \\
\hline 2,010 & 12 & 0,571 & 0,429 & 0,300 & 0,632 & 0,368 & 0,06015 \\
\hline 2,011 & 13 & 0,619 & 0,381 & 0,309 & 0,684 & 0,316 & 0,06516 \\
\hline 2,023 & 14 & 0,667 & 0,333 & 0,435 & 0,737 & 0,263 & 0,07018 \\
\hline 2,033 & 15 & 0,714 & 0,286 & 0,538 & 0,789 & 0,211 & 0,07519 \\
\hline 2,073 & 16 & 0,762 & 0,238 & 0,934 & 0,842 & 0,158 & 0,08020 \\
\hline 2,080 & 17 & 0,810 & 0,190 & 1,004 & 0,895 & 0,105 & 0,08521 \\
\hline 2,121 & 18 & 0,857 & 0,143 & 1,419 & 0,947 & 0,053 & 0,09023 \\
\hline 2,121 & 19 & 0,905 & 0,095 & 1,422 & 1,000 & 0,000 & 0,09524 \\
\hline 2,124 & 20 & 0,952 & 0,048 & 1,452 & 1,053 & $-0,053$ & 0,10025 \\
\hline
\end{tabular}

Sumber : Hasil Perhitungan

Rekapitulasi Uji Smirnov-Kolmogorov Uji smirnov-kolmogorov test

Data $=20 ;$ Signifikan $(\%)=5 ; \Delta_{\text {kritis }} / \mathrm{D}_{0}=0,2940 ;$ dan $\Delta_{\text {maksimum }} / \mathrm{D}_{\max }=0,10025$

Dari perhitungan nilai $\mathrm{D}$ diatas, menunjukkan bahwa nilai $\mathrm{D}_{\max }=0.10025$ data pada peringkat $\mathrm{m}=20$. Dengan menggunakan data pada Tabel SmirnovKolmogorov, untuk derajat kepercayaan $5 \%$, maka diperoleh Do $=0.2940$. Karena nilai $\mathrm{D}_{\max }$ lebih kecil dari nilai Do kritis $(0.10025<0.2940)$, maka persamaan distribusi yang diperoleh (Dapat Diterima)

\section{Waktu Konsentrasi}

Perhitungan waktu konsentrasi pada kawasan perumahan meliputi perhitungan waktu aliran air pada permukaan lahan (to), perhitungan waktu aliran air pada saluran (td), dan perhitungan waktu aliran air pada titik yang ditinjau (tc) yang disebut juga sebagai waktu konsentrasi. 


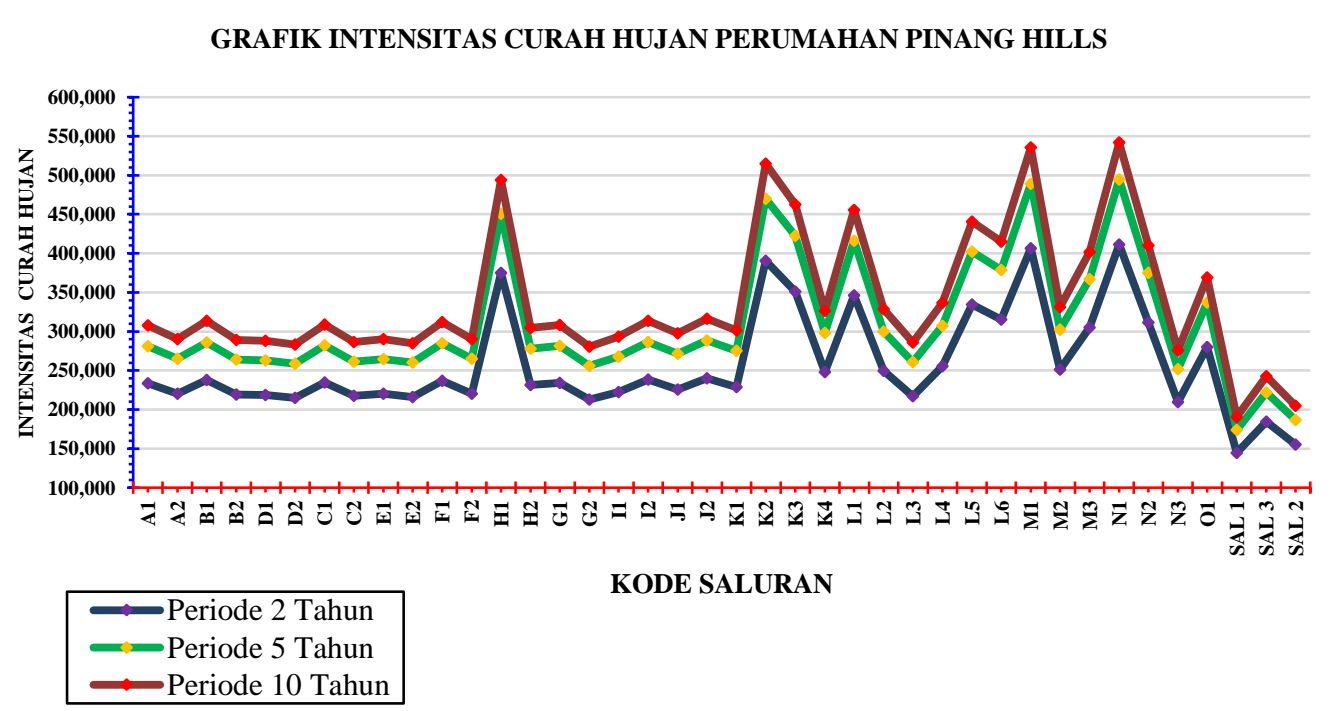

Gambar 2 Grafik Intensitas Curah Hujan Maksimum Perumahan Jalan Damai

\section{Debit Banjir Rencana}

Debit Air Hujan

Contoh Perhitungan Debit air hujan area Blok A saluran A1 kala ulang 10 tahun

Diket:

Koefisien Pengaliran : 0,666

Luas Area $\quad: 0,00089 \mathrm{KM} 2$

Intensitas Hujan : $307,890 \mathrm{~mm} / \mathrm{jam}$

$\mathrm{Q}=0,278 \times \mathrm{C} \times \mathrm{I} \times \mathrm{A} ; \mathrm{Q}=0,278 \times 0,666 \times 307,890 \mathrm{~mm} / \mathrm{jam} \times 0,000890 \mathrm{~km}^{2}$ $\mathrm{Q}=0,051 \mathrm{~m}^{3} /$ detik

\section{Debit Air Kotor}

Untuk memperkirakan jumlah air kotor yang akan dialirkan ke saluran drainase harus diketahui terlebih dahulu jumlah kebutuhan air rata-rata dan jumlah penduduk daerah perencanaan.

Contoh perhitungan debit air kotor area blok A saluran A1:

Diket:

Jumlah Rumah : 4 rumah $=4$ x $5=20$ Orang

Jumlah Kebutuhan Air Kotor : $1,25.10^{-6} \mathrm{~m}^{3} / \mathrm{det} /$ orang

Q air Kotor $=\mathrm{P} \times \mathrm{q}$

$$
\begin{aligned}
& =20 \times 1,25 \cdot 10^{-6} \\
& =0,0000250 \mathrm{~m}^{3} / \mathrm{det}
\end{aligned}
$$

Debit aliran yang akan digunakan untuk menghitung dimensi saluran didapat dari debit yang berasal dari limpahan air hujan dan debit air limbah rumah tangga, dengan rumus:

$\mathrm{Q}_{\text {total }}=\mathrm{Q}_{\text {air hujan }}+\mathrm{Q}_{\text {air limbah rumah tangga }}\left(\mathrm{m}^{3} /\right.$ detik $)$

Contoh perhitungan debit rencana area Blok A saluran A1

Diket :

$\mathrm{Q}_{\text {air hujan }}=0,051$; dan $\mathrm{Q}_{\text {air Kotor }} \quad=0,0000250$ 
Penyelesaian :

$$
\begin{aligned}
\mathrm{Q}_{\text {total }} & =\mathrm{Q}_{\text {air hujan }}+\mathrm{Q}_{\text {air limbah rumah tangga }}\left(\mathrm{m}^{3} / \text { detik }\right) \\
& =0,051+0,0000250\left(\mathrm{~m}^{3} / \text { detik }\right) \\
& =0,051\left(\mathrm{~m}^{3} / \text { detik }\right)
\end{aligned}
$$

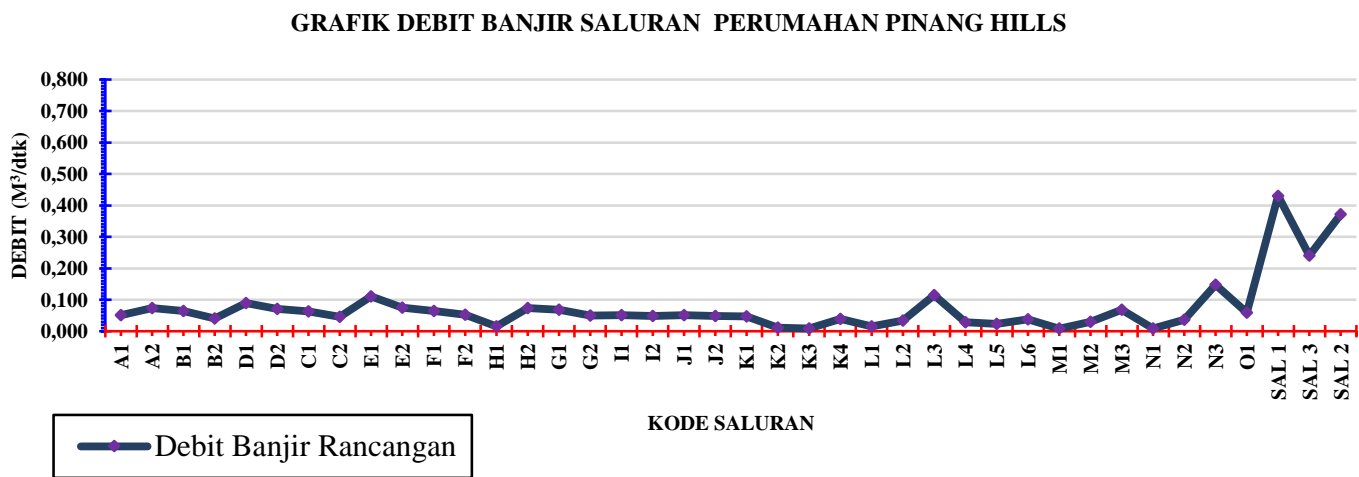

Gambar 3. Grafik Debit Banjir Saluran Perumahan Jalan Damai

\section{Analisis Hidrolika}

Perhitungan dimensi saluran persegi ekonomis

Bentuk penampang melintang persegi yang paling ekonomis adalah jika kedalaman air setengah dari lebar lebar dasar saluran, atau jari-jari hidroliknya setengah dari kedalaman air.

a. Perhitungan tinggi kedalaman air pada

Saluran $1 /$ SAL 1

Diket:

Qbanjir : 0,430 $\mathrm{m}^{3} / \mathrm{dtk}$

n $: 0,015$

S : 0,048

A $\quad: 2 . h^{2}$

$\mathrm{R} \quad: \frac{1}{2} \mathrm{~h}=\frac{\mathrm{h}}{2}$

Penyelesaian :

$\mathrm{V}=\frac{1}{\mathrm{n}} \cdot \mathrm{R}^{\frac{2}{3}} \cdot \mathrm{S}^{\frac{1}{2}}$

$\mathrm{Q}=\mathrm{A} \cdot \mathrm{V}$

$\mathrm{Q}=2 \cdot \mathrm{h}^{2} \cdot \frac{1}{\mathrm{n}} \cdot \mathrm{R}^{\frac{2}{3}} \cdot \mathrm{S}^{\frac{1}{2}}$

$\mathrm{Q}=2 \cdot \mathrm{h}^{2} \cdot \frac{1}{\mathrm{n}} \cdot\left(\frac{\mathrm{h}}{2}\right)^{\frac{2}{3}} \cdot \mathrm{S}^{\frac{1}{2}}$

$0,430=2 \cdot h^{2} \cdot \frac{1}{0,015} \cdot\left(\frac{h}{2}\right)^{\frac{2}{3}} \cdot 0,048^{\frac{1}{2}}$ 


$$
\begin{aligned}
& 0,430=2 \cdot h^{2} \cdot \frac{1}{0,015} \cdot\left(\frac{1}{2}\right)^{\frac{2}{3}}(h)^{\frac{2}{3}} \cdot 0,048^{\frac{1}{2}} \\
& 0,430=2 \cdot \frac{1}{0,015} \cdot\left(\frac{1}{2}\right)^{\frac{2}{3}}(h)^{\frac{8}{3}} \cdot 0,048^{\frac{1}{2}} \\
& 0,675=18,402 \cdot(h)^{\frac{8}{3}} \\
& \frac{0,430}{18,402}=(h)^{\frac{8}{3}} \\
& (h)^{\frac{8}{3}}=0,023 \\
& h=(0,023)^{\frac{3}{8}} \\
& h=0,245 \text { meter }
\end{aligned}
$$

b. Perhitungan lebar dasar saluran

$\mathrm{B}=2 . \mathrm{h} ; \mathrm{B}=2.0,245=0,489$ meter

c. Perhitungan luas penampang basah

$\mathrm{A}=\mathrm{B} . \mathrm{h} ; \mathrm{A}=0,489.0,245=0,120 \mathrm{~m}^{2}$

d. Perhitungan Keliling basah

$\mathrm{P}=\mathrm{B}+2 \mathrm{~h} ; \mathrm{P}=0,489+2.0,245=0,978$ meter

e. Perhitungan jari-jari hidrolik

$\mathrm{R}=\frac{\mathrm{h}}{2}$

$\mathrm{R}=\frac{0,245}{2}$

$\mathrm{R}=0,122$ meter

f. Perhitungan Tinggi Jagaan

$\mathrm{W}=\sqrt{0,5 \cdot \mathrm{h}}$

$\mathrm{W}=\sqrt{0,5 \cdot 0,245}$

$\mathrm{W}=0,350$ meter

Nilai tinggi jagaan berdasarkan tabel 2.14 pada Bab 2 diperoleh sebesar 0,2 $\mathrm{m}$

g. Perhitungan Kecepatan

$\mathrm{V}=\frac{1}{\mathrm{n}} \times \mathrm{R}^{\frac{2}{3}} \times \mathrm{S}^{\frac{1}{2}}$

$\mathrm{V}=\frac{1}{0,015} \times 0,122^{\frac{2}{3}} \times 0,048^{\frac{1}{2}}$

$\mathrm{V}=66,67 \times 0,246 \times 0,219$

$\mathrm{V}=3,597 \mathrm{~m} / \mathrm{dtk}$ 
Tabel 9. Perhitungan Dimensi Penampang Saluran Ekonomis

\begin{tabular}{|c|c|c|c|c|c|c|c|c|c|c|c|c|}
\hline \multirow[t]{2}{*}{ No } & \multirow{2}{*}{$\begin{array}{c}\text { Blok/ } \\
\text { Kode } \\
\text { Saluran }\end{array}$} & \multirow{2}{*}{$\begin{array}{c}\text { Debit } \\
\text { Banjir } \\
\left(\mathrm{m}^{3} /\right. \\
\text { detik })\end{array}$} & \multirow[t]{2}{*}{$\mathrm{S}$} & \multirow[t]{2}{*}{$\mathrm{n}$} & \multirow[t]{2}{*}{ (h) } & \multirow[t]{2}{*}{ (B) } & \multirow[t]{2}{*}{ (A) } & \multirow[t]{2}{*}{ (P) } & \multirow[t]{2}{*}{ (R) } & \multicolumn{2}{|c|}{$\begin{array}{l}\text { Tinggi Jagaan } \\
\text { (w) }\end{array}$} & \multirow[t]{2}{*}{$\begin{array}{c}\text { Kec. } \\
(\mathrm{v}) \\
(\mathrm{m} / \\
\text { detik) }\end{array}$} \\
\hline & & & & & & & & & & Rms & Tbl & \\
\hline & Blok A & & & & & & & & & & & \\
\hline 1 & A1 & 0,051 & 0,366 & 0,015 & 0,075 & 0,150 & 0,011 & 0,300 & 0,037 & 0,194 & 0,200 & 4,513 \\
\hline \multirow[t]{2}{*}{2} & A2 & 0,074 & 0,197 & 0,015 & 0,097 & 0,194 & 0,019 & 0,388 & 0,049 & 0,220 & 0,200 & 3,937 \\
\hline & Blok B & & & & & & & & & & & \\
\hline 3 & B1 & 0,064 & 0,174 & 0,015 & 0,094 & 0,188 & 0,018 & 0,376 & 0,047 & 0,217 & 0,200 & 3,625 \\
\hline \multirow[t]{2}{*}{4} & B2 & 0,040 & 0,126 & 0,015 & 0,084 & 0,168 & 0,014 & 0,335 & 0,042 & 0,205 & 0,200 & 2,857 \\
\hline & Blok D & & & & & & & & & & & \\
\hline 5 & D1 & 0,089 & 0,228 & 0,015 & 0,101 & 0,202 & 0,020 & 0,405 & 0,051 & 0,225 & 0,200 & 4,355 \\
\hline \multirow[t]{2}{*}{6} & D2 & 0,070 & 0,160 & 0,015 & 0,099 & 0,198 & 0,020 & 0,396 & 0,049 & 0,222 & 0,200 & 3,599 \\
\hline & Blok C & & & & & & & & & & & \\
\hline 7 & $\mathrm{C} 1$ & 0,064 & 0,198 & 0,015 & 0,092 & 0,183 & 0,017 & 0,366 & 0,046 & 0,214 & 0,200 & 3,795 \\
\hline \multirow[t]{2}{*}{8} & $\mathrm{C} 2$ & 0,045 & 0,128 & 0,015 & 0,087 & 0,175 & 0,015 & 0,350 & 0,044 & 0,209 & 0,200 & 2,965 \\
\hline & Blok E & & & & & & & & & & & \\
\hline 9 & E1 & 0,110 & 0,191 & 0,015 & 0,113 & 0,227 & 0,026 & 0,453 & 0,057 & 0,238 & 0,200 & 4,294 \\
\hline 10 & E2 & 0,075 & 0,130 & 0,015 & 0,105 & 0,211 & 0,022 & 0,422 & 0,053 & 0,230 & 0,200 & 3,381 \\
\hline & Blok F & & & & & & & & & & & \\
\hline 11 & F1 & 0,064 & 0,193 & 0,015 & 0,092 & 0,184 & 0,017 & 0,368 & 0,046 & 0,215 & 0,200 & 3,762 \\
\hline 12 & $\mathrm{~F} 2$ & 0,052 & 0,025 & 0,015 & 0,125 & 0,251 & 0,031 & 0,501 & 0,063 & 0,250 & 0,200 & 1,663 \\
\hline & Blok H & & & & & & & & & & & \\
\hline 13 & H1 & 0,016 & 0,248 & 0,015 & 0,052 & 0,103 & 0,005 & 0,207 & 0,026 & 0,161 & 0,200 & 2,905 \\
\hline 14 & $\mathrm{H} 2$ & 0,073 & 0,207 & 0,015 & 0,096 & 0,192 & 0,018 & 0,383 & 0,048 & 0,219 & 0,200 & 4,002 \\
\hline & Blok G & & & & & & & & & & & \\
\hline 15 & G1 & 0,068 & 0,184 & 0,015 & 0,095 & 0,190 & 0,018 & 0,380 & 0,048 & 0,218 & 0,200 & 3,749 \\
\hline 16 & G2 & 0,050 & 0,206 & 0,015 & 0,083 & 0,166 & 0,014 & 0,332 & 0,041 & 0,204 & 0,200 & 3,623 \\
\hline & Blok I & & & & & & & & & & & \\
\hline 17 & I1 & 0,051 & 0,290 & 0,015 & 0,078 & 0,157 & 0,012 & 0,313 & 0,039 & 0,198 & 0,200 & 4,138 \\
\hline 18 & I2 & 0,048 & 0,266 & 0,015 & 0,078 & 0,156 & 0,012 & 0,313 & 0,039 & 0,198 & 0,200 & 3,962 \\
\hline & Blok J & & & & & & & & & & & \\
\hline 19 & $\mathrm{~J} 1$ & 0,050 & 0,295 & 0,015 & 0,078 & 0,156 & 0,012 & 0,312 & 0,039 & 0,197 & 0,200 & 4,158 \\
\hline 20 & $\mathrm{~J} 2$ & 0,048 & 0,234 & 0,015 & 0,080 & 0,160 & 0,013 & 0,320 & 0,040 & 0,200 & 0,200 & 3,773 \\
\hline & Blok K & & & & & & & & & & & \\
\hline 21 & K1 & 0,048 & 0,235 & 0,015 & 0,079 & 0,159 & 0,013 & 0,318 & 0,040 & 0,199 & 0,200 & 3,761 \\
\hline 22 & K2 & & 263 & 0,015 & 0,045 & 0,089 & 0,004 & 0,178 & 0,022 & 0,149 & 0,200 & 2,711 \\
\hline 23 & K3 & 0,008 & 0,339 & 0,015 & 0,039 & 0,077 & 0,003 & 0,155 & 0,019 & 0,139 & 0,200 & 2,794 \\
\hline 24 & $\mathrm{~K} 4$ & 0,039 & 0,199 & 0,015 & 0,076 & 0,152 & 0,012 & 0,304 & 0,038 & 0,195 & 0,200 & 3,363 \\
\hline & Blok L & & & & & & & & & & & \\
\hline 25 & L1 & 0,015 & 0,330 & 0,015 & 0,049 & 0,097 & 0,005 & 0,195 & 0,024 & 0,156 & 0,200 & 3,214 \\
\hline 26 & L2 & 0,03 & 0,211 & 0,01 & 0,072 & 0,143 & 0,01 & 0,286 & 0,036 & 0,189 & 0,200 & 3,328 \\
\hline 27 & L3 & 0,115 & 0,000 & 0,015 & 0,366 & 0,732 & 0,268 & 1,465 & 0,183 & 0,428 & 0,200 & 0,427 \\
\hline 28 & L4 & 0,029 & 0,172 & 0,015 & 0,070 & 0,140 & 0,010 & 0,279 & 0,035 & 0,187 & 0,200 & 2,952 \\
\hline 29 & L5 & 0,023 & 0,105 & 0,015 & 0,070 & 0,140 & 0,010 & 0,279 & 0,035 & 0,187 & 0,200 & 2,313 \\
\hline 30 & L6 & 0,038 & 0,059 & 0,015 & 0,095 & 0,189 & 0,018 & 0,378 & 0,047 & 0,217 & 0,200 & 2,122 \\
\hline & Blok N & & & & & & & & & & & \\
\hline 31 & M1 & 0,008 & 0,072 & 0,015 & 0,051 & 0,102 & 0,005 & 0,204 & 0,025 & 0,160 & 0,200 & 1,545 \\
\hline 32 & M2 & & 0,176 & & 0,070 & 0,140 & 0,01 & 0,280 & 0,035 & 0,187 & 0,200 & 2,994 \\
\hline 33 & M3 & 0,069 & 0,032 & 0,015 & 0,132 & 0,265 & 0,035 & 0,530 & 0,066 & 0,257 & 0,200 & 1,958 \\
\hline & Blok N & & & & & & & & & & & \\
\hline 34 & N1 & 0,008 & 0,171 & 0,015 & 0,043 & 0,087 & 0,004 & 0,173 & 0,022 & 0,147 & 0,200 & 2,143 \\
\hline 35 & N2 & 0,036 & 0,150 & 0,015 & 0,078 & 0,156 & 0,012 & 0,312 & 0,039 & 0,198 & 0,200 & 2,974 \\
\hline 36 & N3 & 0,148 & 0,017 & 0,015 & 0,199 & 0,399 & 0,080 & 0,798 & 0,100 & 0,316 & 0,200 & 1,865 \\
\hline & Blok O & & & & & & & & & & & \\
\hline
\end{tabular}




\begin{tabular}{|c|c|c|c|c|c|c|c|c|c|c|c|c|}
\hline No & $\begin{array}{c}\text { Blok/ } \\
\text { Kode } \\
\text { Saluran }\end{array}$ & $\begin{array}{c}\text { Debit } \\
\text { Banjir } \\
\left(\mathrm{m}^{3} /\right. \\
\text { detik })\end{array}$ & $\mathrm{S}$ & $\mathrm{n}$ & $(\mathrm{h})$ & $(\mathrm{B})$ & $(\mathrm{A})$ & (P) & (R) & $\begin{array}{c}\text { Tingi Jagaan } \\
(\mathrm{w})\end{array}$ & $\begin{array}{c}\text { Kec. } \\
(\mathrm{v}) \\
(\mathrm{m} / \\
\text { detik) }\end{array}$ \\
\hline \hline 37 & O1 & 0,059 & 0,004 & 0,015 & 0,184 & 0,367 & 0,067 & 0,734 & 0,092 & 0,303 & 0,200 & 0,872 \\
\hline 38 & SAL 1 & 0,430 & 0,048 & 0,015 & 0,245 & 0,489 & 0,120 & 0,978 & 0,122 & 0,350 & 0,200 & 3,597 \\
\hline 39 & SAL 2 & 0,372 & 0,014 & 0,015 & 0,293 & 0,587 & 0,172 & 1,173 & 0,147 & 0,383 & 0,200 & 2,162 \\
\hline 40 & SAL 3 & 0,240 & 0,093 & 0,015 & 0,173 & 0,347 & 0,060 & 0,694 & 0,087 & 0,294 & 0,200 & 3,991 \\
\hline 41 & Taman & 0,027 & 0,204 & 0,015 & 0,066 & 0,133 & 0,009 & 0,265 & 0,033 & 0,182 & 0,200 & 3,105 \\
\hline
\end{tabular}

Sumber : Hasil Perhitungan

\section{Gambar Penampang Saluran Persegi}

Berdasarkan hasil analisis hidrolika pada saluran perumahan Jalan Damai diperoleh dimensi saluran persegi yang bervariasi, untuk mempermudah pekerjaan dilapangan maka dimensi hasil analisis dilakukan pembulatan. Berikut ini dapat dilihat gambar penampang saluran utama pada perumahan Jalan Damai.

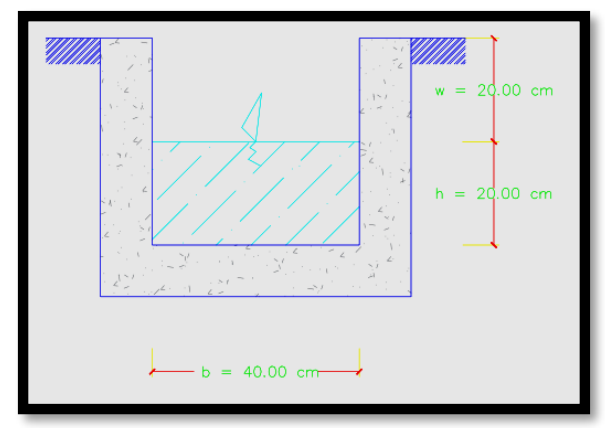

Gambar 4. Penampang Saluran Utama 1

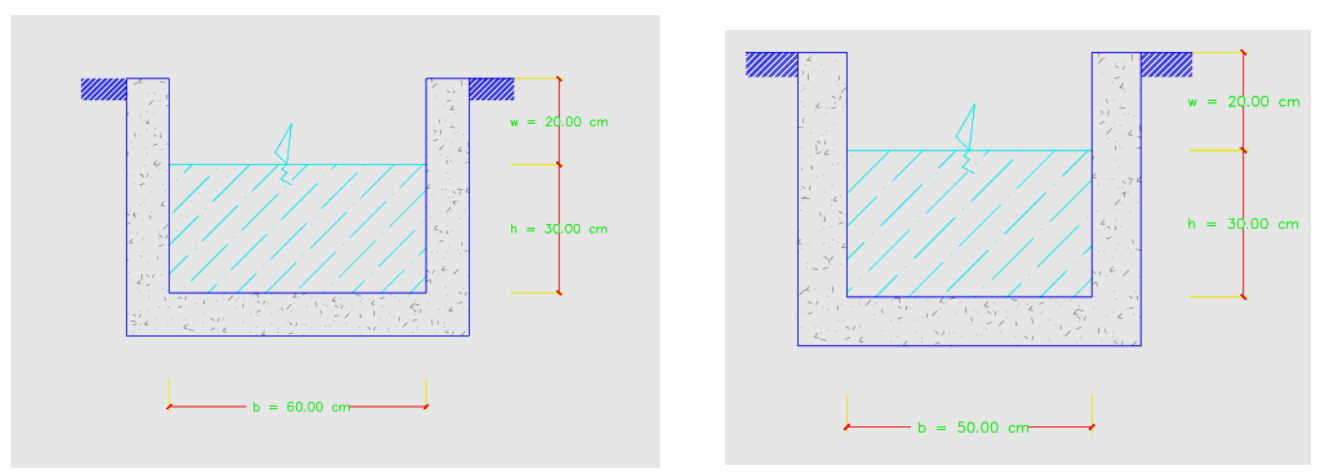

Gambar 5. Penampang Saluran Utama 2 dan 3 


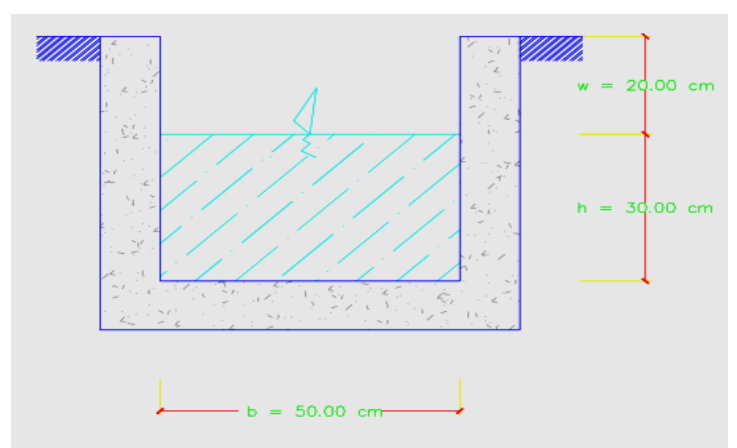

Gambar 6. Penampang Saluran Utama 4

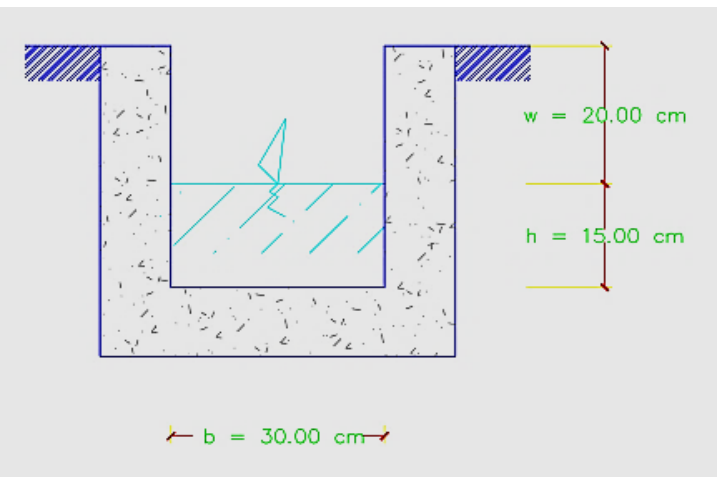

Gambar 7. Penampang Saluran Perumahan

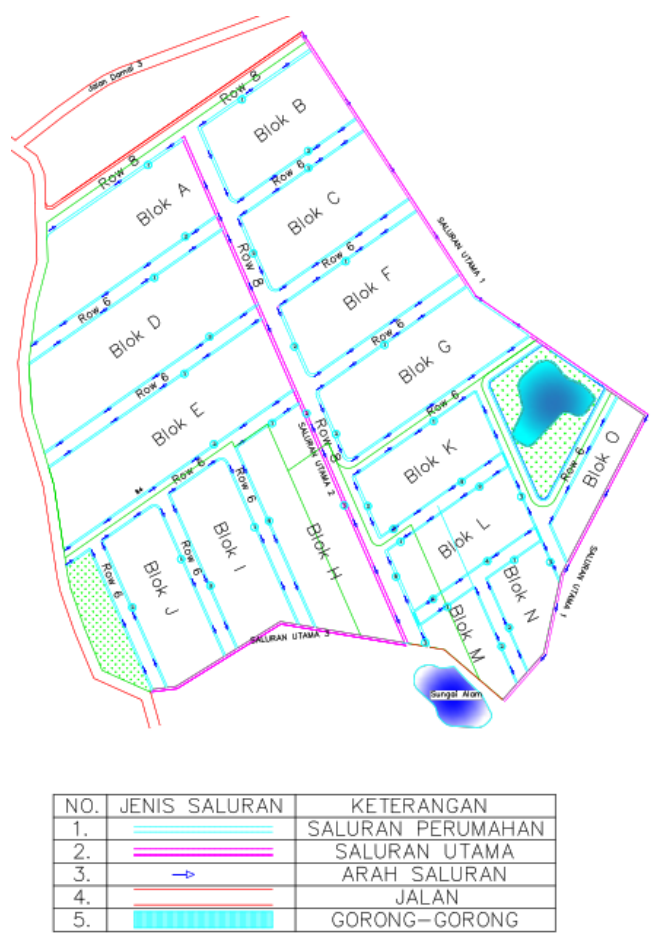

Gambar 8. Desain jaringan Saluran Drainase 


\section{Kesimpulan}

\section{PENUTUP}

Berdasarkan dari penelitian dan pembahasan diambil kesimpulan yaitu sebagai berikut:

1. Desain saluran Perumahan Jalan Damai menggunakan 3 saluran Utama dimana saluran pertama daerah tangkapan airnya berasal dari blok B, C, F, G, K, L, M, $\mathrm{N}$ dan $\mathrm{O}$ kemudian dialirkan ke Sungai alam. Saluran Utama kedua daerah tangkapan airnya berasal dari blok A, D, E,dan taman Blok $\mathrm{H}$ yang di alirkan langsung ke sungai alam. Saluran Utama ketiga daerah tangkapan airnya berasal dari Blok H, I, J, dan taman yang juga di alirkan langsung ke sungai alam.

2. Besarnya debit banjir rencana pada kawasan Perumahan Jalan Damai untuk Kala Ulang 10 Tahun pada saluran Utama ke-satu sebesar $0,430 \mathrm{~m}^{3} /$ detik dengan luas daerah tangkapan Airnya $\pm 13.689,826 \mathrm{~m}^{2}$, saluran Utama ke-dua debit sebesar $0,372 \mathrm{~m}^{3} /$ detik dengan luas daerah tangkapan Airnya \pm $10.591,088 \mathrm{~m}^{2}$, dan saluran Utama ke-tiga debit sebesar $0,240 \mathrm{~m}^{3} /$ detik dengan luas daerah tangkapan Airnya $\pm 6.088,594 \mathrm{~m}^{2}$

3. Dimensi untuk semua saluran di perumahan Jalan Damai menggunakan penampang persegi ekonomis dengan periode ulang 10 tahun dibuat dari pasangan batu di finising dengan dimensi saluran sebagai berikut

a) Saluran Utama 1, kedalaman saluran (h) $30 \mathrm{~cm}$, Lebar dasar saluran (B) 50 $\mathrm{cm}$, tinggi jagaan $20 \mathrm{~cm}$, dan debit desain sebesar $0,618 \mathrm{~m}^{3} / \mathrm{dtk}$

b) Saluran Utama 2, kedalaman saluran (h) $30 \mathrm{~cm}$, Lebar dasar saluran (B) 60 $\mathrm{cm}$, tinggi jagaan $20 \mathrm{~cm}$, dan debit desain sebesar $0,395 \mathrm{~m}^{3} / \mathrm{dtk}$.

c) Saluran Utama 3, kedalaman saluran (h) $20 \mathrm{~cm}$, Lebar dasar saluran (B) 40 $\mathrm{cm}$, tinggi jagaan $20 \mathrm{~cm}$, dan debit desain sebesar $0,351 \mathrm{~m}^{3} / \mathrm{dtk}$.

\section{Saran}

Berdasarkan hasil penelitian dikemukakan beberapa saran yaitu :

1. Untuk penelitian selanjutnya dapat dilakukan penelitian lanjutan dengan menggunakan metode distribusi yang berbeda.

2. Untuk penelitian selanjutnya dapat dilakukan penelitian lanjutan dengan menghitung Gorong-gorong dan Folder.

3. Perlu memperhatikan sistem tata guna lahan yang ada, sehingga dalam pembangunan tidak mengganggu daerah resapan air.

\section{DAFTAR PUSTAKA}

1. Kamiana, I Made. 2011. Teknik Perhitungan Debit Rencana Bangunan Air. Yogyakarta: Graha Ilmu.

2. Kodoatie, Robert. (2003). Banjir. Yogyakarta: Pustaka Pelajar.

3. Loebis, J., 1987. Banjir Rencana Untuk Bangunan Air, Departemen Pekerjaan Umum, Badan Penerbit Pekerjaan Umum, Jakarta.

4. Nugroho Hadisusanto, 2011. Aplikasi Hidrologi, Jogja Mediautama, Yogyakarta. 
5. Oktaviani, Viva., 2016. Studi Perencanaan Sistem Drainase Pada Sirkuit Balap Motor Di Propinsi Kalimantan Timur.Jurnal Sipil Volume IV, No 2, juli 2016, Samarinda.

6. Pania, H.G.,Tangkudung, H., Kawet, L.,Wuisan,E.M.,2013. Perencanaan Sistem Drainase Kawasan Kampus Universitas Sam Ratulangi.Jurnal Sipil Statik Vol 1, No. 3, Manado.

7. Purnama,A., Najimudin, D., Syaripuddin. 2016. Perencanaan Sistem Drainase Untuk Perumahan Baiti Jannati Sumbawa. Jurnal SAINTEK UNSA Vol 1 No. 2 Sumbawa.

8. Soemarto, C. D., 1999. Hidrologi Teknik. Erlangga, Jakarta.

9. Soewarno, 1995. Hidrologi : Aplikasi Metode Statistik untuk Analisa Data Jilid I dan II, Nova Offset, Bandung.

10. Subarkah, Iman.1980. Hidrologi untuk Perencanaan Bangunan Air,. Idea Dharma, Bandung.

11. Suripin, M. Eng, 2004. Sistem Drainase Perkotaan yang Berkelanjutan, Andi Offset, Yogyakarta.

12. Suroso, Suharyanto A., Anwar M.R., Pudyono, Wicaksono D.H,2014. Evaluasi Dan Perencanaan Ulang Saluran Drainase Pada Kawasan Perumahan Sawojajar Kecamatan Kedungkandang Kota Malang, JURNAL REKAYASA SIPIL / Volume 8, No.3 - 2014 hal 207-213, Malang.

13. Yuwono, B, 2012. Tata Cara Penyusunan Rencana Induk Sistem Drainase Perkotaan, Direktorat Jenderal Cipta Karya, Jakarta. 